\section{Gro-Mate Soil Amendment Improves Growth of Greenhouse-grown 'Chardonnay' Grapevines}

\author{
Andrew G. Reynolds ${ }^{1}$, Douglas A. Wardle ${ }^{2}$, Brian Drought ${ }^{3}$, and \\ Robert Cantwell ${ }^{4}$ \\ Agriculture and Agri-Food Canada, Research Center, Summerland, B.C. VOH \\ 1Z0, Canada
}

Additional index words. Vitis vinifera, humate, organic matter, pot culture

\begin{abstract}
Own-rooted, glasshouse-grown 'Chardonnay' vines (Vitis vinifera L.) were planted in a sand medium to which was added one of five levels of granular Gro-Mate (GM), a commercial humate $(0,8,16,32,64 \mathrm{~g} / \mathrm{pot} ; 0$ to $35 \mathrm{~g}$ a.i./pot $)$. Two other treatments consisted of weekly $(1 \times W)$ or twice-weekly $(2 \times W)$ applications of liquid GM, whose cumulative addition over the 28 weeks of the experiment totaled 6.7 and $13.4 \mathrm{~g}$ a.i., respectively. Shoot length responded to increasing level of GM in a predominantly cubic fashion, with $32 \mathrm{~g} /$ pot resulting in the longest shoots. Fresh and dry weights of leaves, shoots, and roots, as well as leaf count and area, exhibited increasing linear or quadratic trends in response to increased level of granular GM. GM increased soil organic matter, $\mathrm{K}, \mathrm{Ca}, \mathrm{Mg}, \mathrm{Fe}, \mathrm{Mn}, \mathrm{Cu}, \mathrm{Na}$, and $\mathrm{S}$ and also increased petiole $\mathrm{Fe}$ and lamina $\mathrm{P}, \mathrm{K}$, and $\mathrm{Fe}$. Liquid treatment resulted in lower soil $\mathrm{pH}$, organic matter, bulk density, and $\mathrm{Fe}$ and higher soil conductivity, $\mathrm{NO}_{3}, \mathrm{P}, \mathrm{K}, \mathrm{Mg}, \mathrm{Cu}, \mathrm{Zn}, \mathrm{Na}$, and $\mathrm{S}$ than the granular treatments, as well as higher petiole and lamina $N$ and $K$, lower petiole and lamina $P$, and lower petiole $Z n$. Compared to the $1 \times W$ treatment, the $2 \times W$ produced lower soil bulk density and higher $\mathrm{P}$, lower lamina $\mathrm{K}$, Mn, and $\mathrm{Fe}$; lower petiole $\mathrm{Mn}$; and higher petiole $\mathrm{Cu}$. Plant tissues contained extremely high levels of Mn irrespective of treatment, whereas liquid treatments resulted in high soil $\mathrm{NO}_{3}$ levels. Although liquid GM cannot be recommended for young grapevines under an application regime such as described here, preplant applications of granular GM may have potential for improving growth of young vines in coarse-textured soils. High granular or excessive liquid applications may result in leaf necrosis and retarded growth.
\end{abstract}

Commercial humates have been tested on a multitude of horticultural crops (Bryan, 1976; Burdick, 1965; Linderman, 1989; Rauthan and Schnitzer, 1981; Schnitzer and Poapst, 1967; Senn and Kingman, 1973; Tan and Nopamornbodi, 1979) for their ability to promote plant growth through increases in soil water-holding capacity and cation exchange capacity (CEC). Gro-Mate (GM) (Humate Canada, Calgary, Alberta) is an example of such an organic soil amendment, containing humic acid, one of the active ingredients in soil organic matter. In the coarse-textured soils of the Okanagan and Similkameen valleys of British Columbia, commercial humates may prove valuable by adding sufficient humic acid to increase the CEC and water-holding capacity of the soil. Products such as GM

Received for publication 16 June 1994. Accepted for publication 19 Dec. 1994. Summerland Research Center contribution no. 892. The cost of publishing this paper was defrayed in part by the payment of page charges. Under postal regulations, this paper therefore must be hereby marked advertisement solely to indicate this fact.

${ }^{1}$ Research Scientist, Horticulture and Basic Studies. ${ }^{2}$ Research Assistant, Horticulture and Basic Studies.

${ }^{3}$ Research Assistant, Environmental Studies.

${ }^{4}$ Humate Canada, Calgary, Alberta T3C 3W2, Canada. thus may aid the establishment of young vineyards, as well as improve the growth of vines in nurseries. The purpose of this experiment was to evaluate the efficacy of GM as a growthpromoting substance on potted 'Chardonnay' vines grown in a greenhouse.

\section{Materials and Methods}

Own-rooted 'Chardonnay' vines were planted in Dec. 1991 into 5-liter plastic pots containing coarse sand (hereinafter referred to as "soil"). The vines were divided equally into seven groups (treatments) of 18 vines each, and one of five levels of granular GM (active ingredients 55\% humic acid + fulvic acid + humin; $0,8,16,32$, and $64 \mathrm{~g}$ material/pot) was incorporated into the sand in five of the seven treatment groups. Active ingredients of granular GM were 0, 4.4, 8.8, 17.6, and $35.2 \mathrm{~g}$ a.i./ pot. The two remaining treatments received a 400 -ml weekly $(1 \times \mathrm{W})$ and twice-weekly $(2 \times$ W) application, respectively, of $4 \mathrm{ml}$ liquid GM (15\% humic acid + fulvic acid + humin) per liter of water (600 $\mathrm{mg}$ a.i./liter). The liquid GM treatments constituted 6.7 and $13.4 \mathrm{~g}$ a.i./ pot, with the initial assumption that 1) the experiment's duration would be 28 weeks from the point of the initial liquid application on 2 Mar. 1992 (28 1× W and $562 \times \mathrm{W}$ applications, respectively), and 2) the liquid treatments would be applied as 400-ml aliquots. The seven treatments were arranged as a ran- domized complete-block experiment with six blocks and three-vine treatment replications. Vines were trained to single shoots and all crop was removed. The greenhouse was at 26C day/20C night. Supplementary lighting was supplied for $6 \mathrm{~h} /$ day (0600-0900 HR and 1600-1900 HR) by high-intensity sodium lamps. Vines were watered twice weekly with $400 \mathrm{ml}$ water containing $0.5 \mathrm{mg} 20 \mathrm{~N}-20 \mathrm{P}-$ $20 \mathrm{~K}$ soluble fertilizer/liter with trace elements (Plant Products Co., Brampton, Ont.); solutions for the $1 \times \mathrm{W}$ and $2 \times \mathrm{W}$ treatments were also made from this water-fertilizer mixture. Trace element concentrations in the soluble

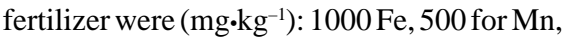
$\mathrm{Cu}$, and $\mathrm{Zn}$, and $200 \mathrm{~B}$; or 0.005, 0.0025, and $0.001 \mathrm{mg} \cdot \mathrm{kg}^{-1}$ irrigation water, respectively.

Cumulative shoot length was measured at $\approx 6$-week intervals beginning on 9 Apr. 1992. Fresh and dry weight of leaves, petioles, shoots, and roots were collected from each vine at the conclusion of the experiment in Nov. 1992. Leaf count and area of main leaves and lateral shoot leaves also were measured at that time. Elemental analysis was performed on three 50-g GM samples; three-vine composite (i.e., each treatment replication), 50-g, air-dried soil samples; and oven-dried lamina and petiole samples, using previously described methods (Neilsen et al., 1987).

All data were analyzed using the SAS statistical package (SAS Inst., Cary, N.C.). Analysis of variance was accomplished using the GLM procedure. Relationships within the five granular GM levels, between the granular and liquid treatments, and within the two liquid treatments were ascertained through the use of single-degree-of-freedom contrasts.

\section{Results and Discussion}

Vegetative growth. Shoot length was highest with 32 and $64 \mathrm{~g} \mathrm{GM} /$ pot at the first measurement date, but subsequently only the 32-g application showed appreciable advantage over the control and other treatments (Fig. 1). The trend in the data was linear with increasing level of GM for the first measurement date, but predominantly cubic thereafter. Little, if any, shoot growth enhancement occurred between 0 and $16 \mathrm{~g} \mathrm{GM} /$ pot, and shoot growth was suppressed at $64 \mathrm{~g} \mathrm{GM}$. The $1 \times \mathrm{W}$ and $2 \times \mathrm{W}$ treatments initially had no apparent effect on shoot growth, but led to obvious growth inhibition throughout the remainder of the trial (Fig. 1). These two liquid GM treatments and $64 \mathrm{~g} \mathrm{GM}$ of granular material also caused significant adult leaf chlorosis and marginal necrosis and cupping of young leaves. The conductivity induced by $64 \mathrm{~g}$ GM and by the liquid treatments may have been high enough at application to harm the roots and cause a salt effect consistent with these foliar symptoms.

Increasing levels of granular GM increased leaf count per vine, leaf area per vine, fresh and dry weight of leaves, and dry weight of petioles (Table 1). Fresh and dry weight of stems followed cubic trends in which $32 \mathrm{~g} /$ pot was superior to the other concentrations. Fresh and dry weights of roots followed quadratic (para- 


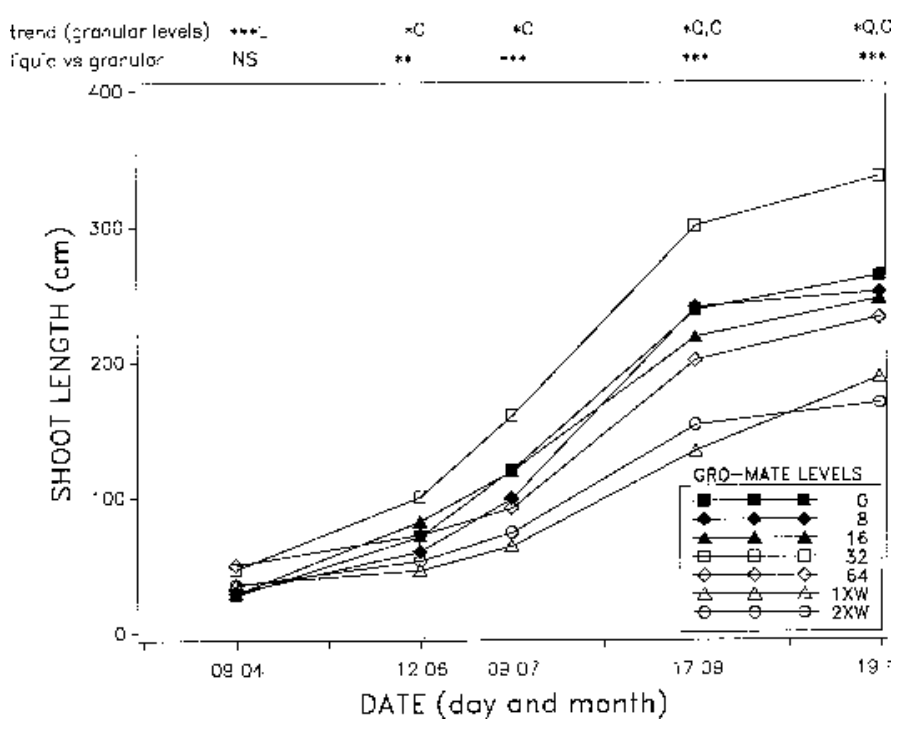

Fig. 1. Cumulative shoot length of potted 'Chardonnay' vines subjected to five concentrations (grams/pot) of granular Gro-Mate $(\mathrm{GM})$ and two application frequencies [once weekly $(1 \times \mathrm{W})$ and twice weekly $(2 \times$ W)] of liquid GM, from 9 Apr. to 19 Nov. 1992. The upper row of asterisks refers to the trends in the data from the five granular levels, while the lower row refers to differences between the granular and liquid treatments. ${ }^{\text {s., }{ }^{*}, *, * * *}$ Nonsignificant or significant at $P \leq 0.05,0.01$, or 0.001 , respectively; $\mathrm{L}, \mathrm{Q}, \mathrm{C}$ : linear, quadratic, or cubic trends, respectively.

bolic) trends, wherein plants with 16 and $32 \mathrm{~g} /$ pot exceeded the rest. All aspects of leaf area, fresh weight, and dry weight per vine were reduced relative to the granular form and mostly relative to the control by the liquid treatments (Table 1). The $2 \times \mathrm{W}$ treatment also reduced leaf count, leaf area per vine, and dry weight of leaves relative to the $1 \times \mathrm{W}$ treatment. These results suggest that, although $16 \mathrm{~g} \mathrm{GM} /$ pot failed to increase shoot length, there was nonetheless some effect in increased biomass of roots. Also, despite a lack of shoot growth increase in the 64-g GM vines, leaf count, total leaf area, and fresh and dry weight of leaves were increased.

These data confirm those of Bryan (1976), Schnitzer and Poapst (1967), and Rauthan and Schnitzer (1981), who, respectively, found increases in tomato (Lycopersicon esculentum L.) seedling growth, bean (Phaseolus vulgaris L.) seedling root growth, and cucumber (Cucumis sativus L.) root and shoot growth in response to commercial humate additions. In most cases, these researchers found responses similar to those in this study; however, high rates of humates also tended to restrict height and cotyledon area of tomato seedlings (Bryan, 1976); root initiation of bean seedlings (Schnitzer and Poapst, 1967); and cucumber plant height, root length, leaf and flower number, and dry weight of roots and shoots (Rauthan and Schnitzer, 1981).

Nutrient concentrations in plants. Nutrient concentrations in the petioles were within normal ranges for $\mathrm{K}, \mathrm{Ca}, \mathrm{Mg}$, and $\mathrm{Cu}$; high for $\mathrm{P}$; very high for $\mathrm{Mn}$ and $\mathrm{Zn}$; and low for $\mathrm{Fe}$, based on recommended concentration ranges for local vineyards [British Columbia Ministry of Agriculture, Fisheries, and Food (BCMAFF), 1993]. Increasing level of granular GM increased petiole Fe, but had no effect on other elements (Table 2). Use of liquid GM increased petiole $\mathrm{N}$ and $\mathrm{K}$, but decreased $\mathrm{P}$ and Zn (Table 2). Twice-weekly liquid applications of this product decreased petiole $\mathrm{Mn}$, but increased petiole $\mathrm{Cu}$ (Table 2). Elemental con- centrations in the lamina were normal for $\mathrm{P}, \mathrm{K}$, $\mathrm{Ca}, \mathrm{Mg}, \mathrm{Fe}, \mathrm{Cu}$, and $\mathrm{Zn}$, but were high for $\mathrm{N}$ and extremely high for Mn. In the lamina, increasing the amount of granular GM decreased $\mathrm{K}$ but increased $\mathrm{Fe}$ (Table 2). A quadratic trend showed that lamina $\mathrm{P}$ increased with increasing granular GM up to $32 \mathrm{~g} /$ pot, then decreased (Table 2). Use of the liquid formulation increased lamina $\mathrm{N}$ and $\mathrm{K}$, but decreased $\mathrm{P}$; twice-weekly application decreased lamina $\mathrm{K}, \mathrm{Mn}$, and $\mathrm{Fe}$ over those observed in the $1 \times \mathrm{W}$ vines (Table 2 ).

The most striking feature of these data are the extremely high petiole and lamina $\mathrm{Mn}$ concentrations, which are 6 to 8 times higher than the upper normal limit $\left(150 \mathrm{mg} \cdot \mathrm{kg}^{-1}\right)$ for Vitis vinifera in this region (BCMAFF, 1993). However, Stevenson (unpublished data, 1971) found $\mathrm{Mn}$ concentrations $>500 \mathrm{mg} \cdot \mathrm{kg}^{-1}$ in 'Diamond' ( $V$. labruscana Bailey) petioles sampled from healthy vines growing in permanent sod cover crop and provided with medium irrigation frequency (Stevenson, 1975). Petiole Fe levels were extremely low. Also notable are the increased $\mathrm{K}$ and reduced $P$ levels in the tissues following use of the liquid formulations. This combination of phenomena were the only significant trends in the plant tissue data that could account for the substantially reduced growth rate and the cupped, chlorotic, necrotic leaves in the liquid treatments. The relatively low levels of $\mathrm{N}, \mathrm{P}$, and $\mathrm{K}$ in the granular GM (Table 2) likely had no direct effect on concentrations of these elements in tissue, but the high Fe may have been actively absorbed and translocated; however, all tissue Fe levels were low $\left(<40 \mathrm{mg} \cdot \mathrm{kg}^{-1}\right)$ to normal ( 40 to $300 \mathrm{mg} \cdot \mathrm{kg}^{-1}$ ). Despite low tissue $\mathrm{Fe}$, the mostly linear trends in vegetative growth in response to increased granular GM application could not be clearly linked to increases in any element other than tissue Fe. Rauthan and Schnitzer (1981) hypothesized that high concentrations of humates may provide adsorption surfaces for metal ions (primarily Fe, Mn, and $\mathrm{Zn}$ ), which would render these elements partially unavailable.

Our data suggested a preferential uptake of $\mathrm{Mn}$ and $\mathrm{Zn}$ over that of Fe, and imply that although the GM may have been acting as a reservoir for these micronutrients, Fe was ren-

Table 1. Effect of five concentrations (grams/pot) of granular Gro-Mate (GM) and two application frequencies of liquid GM on leaf count, leaf area, fresh weight, and dry weight of greenhouse-grown 'Chardonnay' vines.

\begin{tabular}{|c|c|c|c|c|c|c|c|c|c|c|c|}
\hline \multirow[b]{2}{*}{ Amount/pot (g) } & \multirow{2}{*}{$\begin{array}{l}\text { Leaf count/ } \\
\text { vine }\end{array}$} & \multicolumn{2}{|c|}{ Leaf area $\left(\mathrm{cm}^{2}\right)$} & \multicolumn{3}{|c|}{ Fresh wt (g)/vine } & \multicolumn{5}{|c|}{ Dry wt $(\mathrm{g}) / \mathrm{vine}$} \\
\hline & & Per vine & Per leaf & Leaves & Stems & Roots & Leaves & Petioles & Stems & Roots & Total \\
\hline 0 & 28 & 1264 & 47.1 & 24.0 & 47.2 & 72.3 & 4.79 & 0.57 & 21.1 & 31.6 & 73.5 \\
\hline 8 & 21 & 1118 & 51.8 & 19.3 & 38.5 & 70.5 & 3.67 & 0.43 & 17.0 & 32.8 & 72.4 \\
\hline 16 & 26 & 1335 & 79.5 & 20.2 & 41.4 & 83.5 & 4.34 & 0.49 & 17.6 & 34.8 & 75.7 \\
\hline 32 & 31 & 1668 & 56.1 & 29.1 & 60.8 & 87.3 & 5.65 & 0.74 & 26.9 & 40.2 & 95.0 \\
\hline 64 & 35 & 1707 & 50.9 & 29.2 & 43.8 & 69.7 & 5.70 & 0.70 & 18.9 & 34.5 & 78.1 \\
\hline Weekly $(1 \times W)$ & 33 & 1323 & 39.5 & 20.9 & 22.0 & 45.5 & 4.04 & 0.47 & 8.2 & 25.2 & 57.6 \\
\hline $\begin{array}{l}\text { Twice-weekly } \\
(2 \times W)\end{array}$ & 23 & 962 & 42.7 & 15.2 & 26.7 & 54.0 & 2.87 & 0.33 & 10.4 & 28.9 & 60.5 \\
\hline $\begin{array}{l}\text { Significance } \\
\text { (granular) }\end{array}$ & $\mathrm{L}^{* *}$ & $\mathrm{~L}^{* *}$ & NS & $\mathrm{L}^{* *}$ & $\mathrm{C}^{* *}$ & $\mathrm{Q}^{*}$ & $\mathrm{~L}^{* *}$ & $\mathrm{~L}^{* *}$ & $\mathrm{C}^{* * *}$ & $\mathrm{Q}^{*}$ & $\mathrm{~L}, \mathrm{Q}^{*}$ \\
\hline $\begin{array}{l}\text { Liquid vs. } \\
\text { granular }\end{array}$ & NS & $*$ & $*$ & $* *$ & $* * *$ & $* * *$ & $* * *$ & $* *$ & $* * *$ & $* * *$ & $* * *$ \\
\hline $1 \times \mathrm{W}$ vs. $2 \times \mathrm{W}$ & $* *$ & $*$ & NS & NS & NS & NS & $*$ & NS & NS & NS & NS \\
\hline
\end{tabular}

Ns, ${ }^{*}, * *, * * *$ Nonsignificant or significant at $P \leq 0.05,0.01$, or 0.001 , respectively; L, Q, C: linear, quadratic, or cubic trends, respectively. 
Table 2. Chemical analysis of Gro-Mate (GM), plus effects of five concentrations of granular GM (grams/pot) and two application frequencies of liquid GM on lamina and petiole elemental analysis of greenhouse-grown 'Chardonnay' vines.

\begin{tabular}{|c|c|c|c|c|c|c|c|c|c|}
\hline $\begin{array}{l}\text { Amount/pot } \\
(\mathrm{g})\end{array}$ & $\begin{array}{c}\mathrm{N} \\
(\%)\end{array}$ & $\begin{array}{c}\mathrm{P} \\
(\%) \\
\end{array}$ & $\begin{array}{c}\mathrm{K} \\
(\%) \\
\end{array}$ & $\begin{array}{l}\mathrm{Ca} \\
(\%) \\
\end{array}$ & $\begin{array}{l}\mathrm{Mg} \\
(\%) \\
\end{array}$ & $\begin{array}{c}\mathrm{Mn} \\
\left(\mathrm{mg} \cdot \mathrm{kg}^{-1}\right)\end{array}$ & $\begin{array}{c}\mathrm{Fe} \\
\left(\mathrm{mg} \cdot \mathrm{kg}^{-1}\right)\end{array}$ & $\begin{array}{c}\mathrm{Cu} \\
\left(\mathrm{mg}^{\mathrm{kg}} \mathrm{kg}^{-1}\right)\end{array}$ & $\begin{array}{c}\mathrm{Zn} \\
\left(\mathrm{mg} \cdot \mathrm{kg}^{-1}\right)\end{array}$ \\
\hline & 0.83 & 0.11 & 0.10 & 0.32 & $\begin{array}{c}\text { Gro-Mate } z \\
0.07\end{array}$ & 63.4 & 4206 & 43.7 & 28.3 \\
\hline \\
\hline 8 & 1.10 & 0.86 & 5.31 & 1.23 & 0.23 & 672 & 17.9 & 14.0 & 99.8 \\
\hline 16 & 1.19 & 0.86 & 4.98 & 1.28 & 0.23 & 605 & 18.6 & 11.5 & 100 \\
\hline 32 & 1.33 & 0.85 & 4.85 & 1.20 & 0.25 & 583 & 17.0 & 11.7 & 96.1 \\
\hline 64 & 1.20 & 0.72 & 5.67 & 1.44 & 0.28 & 783 & 21.4 & 12.0 & 108 \\
\hline Weekly $(1 \times W)$ & 1.85 & 0.67 & 6.42 & 1.48 & 0.25 & 840 & 18.7 & 10.2 & 86.4 \\
\hline \multicolumn{10}{|l|}{ Twice weekly } \\
\hline$(2 \times W)$ & 1.79 & 0.54 & 6.41 & 1.36 & 0.34 & 644 & 17.5 & 16.2 & 70.2 \\
\hline \multicolumn{10}{|l|}{ Significance } \\
\hline (granular) & NS & NS & NS & NS & NS & NS & $\mathrm{L}^{*}$ & NS & NS \\
\hline Liquid vs. granular & $* * *$ & $* * *$ & $* * *$ & NS & NS & NS & NS & NS & $*$ \\
\hline $1 \times W$ vs. $2 \times W$ & NS & NS & NS & NS & NS & $*$ & NS & $*$ & NS \\
\hline \multicolumn{10}{|c|}{ Lamina } \\
\hline 0 & 2.81 & 0.95 & 3.16 & 1.32 & 0.24 & 466 & 94.6 & 14.0 & 20.5 \\
\hline 8 & 2.91 & 1.03 & 3.06 & 1.31 & 0.23 & 469 & 97.1 & 13.8 & 22.1 \\
\hline 16 & 2.64 & 1.01 & 3.00 & 1.48 & 0.23 & 527 & 106 & 12.8 & 21.9 \\
\hline 32 & 3.07 & 1.05 & 2.87 & 1.35 & 0.24 & 450 & 101 & 16.0 & 22.7 \\
\hline 64 & 2.81 & 0.82 & 2.67 & 1.45 & 0.25 & 503 & 121 & 13.6 & 21.1 \\
\hline $1 \times \mathrm{W}$ & 3.55 & 0.82 & 4.35 & 1.48 & 0.23 & 624 & 107 & 14.8 & 23.5 \\
\hline $2 \times W$ & 3.70 & 0.73 & 3.83 & 1.21 & 0.25 & 440 & 89.2 & 16.4 & 21.4 \\
\hline \multicolumn{10}{|l|}{ Significance } \\
\hline (granular) & NS & $\mathrm{Q}^{*}$ & $\mathrm{~L}^{*}$ & NS & NS & NS & $\mathrm{L}^{* *}$ & NS & NS \\
\hline Liquid vs. granular & $* * *$ & $* * *$ & $* * *$ & NS & NS & NS & NS & NS & NS \\
\hline $1 \times \mathrm{W}$ vs. $2 \times \mathrm{W}$ & NS & NS & $*$ & NS & NS & $*$ & $*$ & NS & NS \\
\hline
\end{tabular}

${ }^{2} \mathrm{GM}$ also contained $\left(\mathrm{mg} \cdot \mathrm{kg}^{-1}\right): 25,000 \mathrm{Al} ; 9,000 \mathrm{Ti} ; 500 \mathrm{Na}$; and $0.95 \% \mathrm{~S}$

Ns, $, * *, * * *$ Nonsignificant or significant at $P \leq 0.05,0.01,0.001$, respectively; $\mathrm{L}=$ linear, $\mathrm{Q}=$ quadratic.

Table 3. Effects of five concentrations of granular Gro-Mate (GM) (grams/pot) and two application frequencies of liquid GM on soil physical and extractable elemental analysis.

\begin{tabular}{|c|c|c|c|c|c|c|c|c|c|c|c|c|c|c|c|c|}
\hline \multirow[b]{2}{*}{ Amount/pot $(\mathrm{g})$} & \multicolumn{4}{|c|}{ Physical analysis } & \multicolumn{12}{|c|}{ Extractable elemental analysis (mg.kg ${ }^{-1}$ soil) } \\
\hline & $\mathrm{pH}$ & $\mathrm{BD}^{\mathrm{y}}$ & $\mathrm{COND}^{\mathrm{x}}$ & $\begin{array}{l}\mathrm{OM}^{\mathrm{z}} \\
(\%)\end{array}$ & $\mathrm{NO}_{3}$ & $\mathrm{P}$ & $\mathrm{K}$ & $\mathrm{Ca}$ & $\mathrm{Mg}$ & $\mathrm{Fe}$ & $\mathrm{Mn}$ & $\mathrm{Cu}$ & $\mathrm{Zn}$ & $\mathrm{B}$ & $\mathrm{Na}$ & $\mathrm{S}$ \\
\hline 0 & 7.67 & 1.65 & 0.27 & 0.28 & 8.3 & 73 & 106 & 338 & 24.7 & 10.9 & 8.5 & 1.10 & 0.70 & 0.14 & 50 & $\overline{11.5}$ \\
\hline 8 & 7.62 & 1.62 & 0.24 & 0.70 & 6.3 & 88 & 113 & 364 & 26.8 & 11.2 & 9.3 & 1.23 & 0.77 & 0.15 & 50 & 12.3 \\
\hline 16 & 7.60 & 1.62 & 0.23 & 0.37 & 6.2 & 93 & 135 & 374 & 26.3 & 11.0 & 9.7 & 1.22 & 0.68 & 0.19 & 57 & 13.8 \\
\hline 32 & 7.53 & 1.62 & 0.27 & 0.68 & 6.3 & 105 & 127 & 420 & 27.7 & 10.8 & 10.3 & 1.76 & 0.77 & 0.12 & 61 & 14.7 \\
\hline 64 & 7.58 & 1.62 & 0.27 & 0.72 & 8.0 & 93 & 112 & 487 & 32.3 & 9.9 & 8.6 & 1.97 & 0.72 & 0.19 & 60 & 16.2 \\
\hline Weekly $(1 × \mathrm{~W})$ & 7.38 & 1.63 & 0.72 & 0.25 & 43.7 & 129 & 249 & 410 & 34.7 & 8.0 & 8.7 & 1.88 & 0.92 & 0.23 & 77 & 19.2 \\
\hline Twice weekly $(2 × \mathrm{~W})$ & 7.40 & 1.59 & 0.75 & 0.28 & 42.8 & 133 & 276 & 427 & 35.5 & 8.2 & 9.2 & 2.22 & 0.87 & 0.16 & 75 & 19.2 \\
\hline Significance (granular) & NS & NS & NS & $\mathrm{L}^{*}$ & NS & NS & $\mathrm{Q}^{*}$ & $\mathrm{~L}^{* * *}$ & $\mathrm{~L}^{* *}$ & $\mathrm{~L}^{*}$ & $\mathrm{~L}^{*}$ & $\mathrm{~L}^{* * *}$ & NS & NS & $\mathrm{L}^{* *}$ & $\mathrm{~L}^{* * *}$ \\
\hline Liquid vs. granular & ** & $*$ & *** & ** & $* * *$ & *** & $* * *$ & NS & $* * *$ & **** & NS & $* * *$ & ** & NS & $* * *$ & $* * *$ \\
\hline $1 \times \mathrm{W}$ vs. $2 \times \mathrm{W}$ & NS & $*$ & NS & NS & NS & NS & $*$ & NS & NS & NS & NS & NS & NS & NS & NS & NS \\
\hline
\end{tabular}

${ }^{2} \mathrm{OM}=$ organic matter.

${ }^{\mathrm{y}} \mathrm{BD}=$ bulk density $\left(\mathrm{g} \cdot \mathrm{ml}^{-1}\right)$.

${ }^{\mathrm{x}} \mathrm{COND}=$ conductance $\left(\mathrm{dS} \cdot \mathrm{m}^{-1}\right)$.

Ns, ****,***** Nonsignificant or significant at $P \leq 0.05,0.01$, or 0.001 , respectively; $\mathrm{L}=$ linear, $\mathrm{Q}=$ quadratic.

dered partially unavailable. Manganese, however, accumulated in the leaf tissues at potentially toxic levels, although we are not aware of any study that has established a tissue concentration range for $\mathrm{Mn}$ toxicity in grapes. Since high Mn also was found in the control, the source of the Mn was probably the soluble fertilizer in the irrigation water. The high $\mathrm{Mn}$ could thus not have fully explained the chlorotic condition of the adult leaves from the 64g GM treatment, as well as from both liquid treatments in our experiment. Whether the high concentrations of $\mathrm{Al}$ and $\mathrm{Ti}$ in the granular GM were in any way toxic is unknown; however, Le Roux et al. (1988) reported Al toxicities in South African potted grapevines when $\mathrm{Al}$ was added to liquid nutrient medium at $10 \mathrm{mg} \cdot \mathrm{kg}^{-1}$. Theoretical Al concentrations in our granular GM-augmented soils ranged from
40 to $320 \mathrm{mg} \cdot \mathrm{kg}^{-1}$, since GM contained 25,000 $\mathrm{mg} \mathrm{Al} / \mathrm{kg}$.

Nutrient concentrations in soil. As expected, increasing granular GM applications led to linear increases in soil organic matter, along with increases in $\mathrm{Ca}, \mathrm{Mg}, \mathrm{Fe}, \mathrm{Mn}, \mathrm{Cu}$, $\mathrm{Na}$, and $\mathrm{S}$ (Table 3). However, actual organic matter increases over the control were very small and ranged from an additional $0.42 \%$ to $0.44 \%$ for 8 to $64 \mathrm{~g} \mathrm{GM}$; theoretical increases based on measured bulk density were $0.05 \%$ to $0.39 \%$ and were not well-correlated with the actual values. The high $\mathrm{Fe}$ in the granular GM may have had a direct effect on soil Fe. However, $64 \mathrm{~g}$ GM did not lead to noticeable increases in soil $\mathrm{Fe}$ and $\mathrm{Mn}$, and the relationship between soil $\mathrm{K}$ and granular GM level was quadratic. The liquid formulation decreased soil $\mathrm{pH}$, bulk density, organic matter, and $\mathrm{Fe}$, and increased soil conductivity, $\mathrm{NO}_{3}$, $\mathrm{P}, \mathrm{K}, \mathrm{Mg}, \mathrm{Cu}, \mathrm{Zn}, \mathrm{Na}$, and $\mathrm{S}$ compared to the granular applications (Table 3). Use of twiceweekly liquid feedings slightly decreased bulk density compared to weekly applications, but increased soil K (Table 3). Bulk density increases are attributed in this case to added organic matter rather than compaction, since all treatments received equal volumes of water. Based on analyses of local virgin soil (Skaha gravelly sandy loam), physical characteristics of the soil in this experiment were considered within normal ranges, other than slightly lower organic matter (E.J. Hogue, personal communication). Among the elemental analyses, $\mathrm{NO}_{3}, \mathrm{~K}, \mathrm{Ca}, \mathrm{Mg}$, and $\mathrm{S}$ levels were lower than normal. Phosphorus and $\mathrm{Na}$ concentrations were higher than normal, especially with the liquid $\mathrm{GM}$. Soil $\mathrm{NO}_{3}$ following 
application of the liquid formulations was 3 times the normal level found in local coarsetextured soils, and is likely a result of nitrate mineralization following these applications. The exceptionally high concentrations of soil $\mathrm{NO}_{3}, \mathrm{P}$, and $\mathrm{Na}$ due to these liquid treatments, in conjunction with low organic matter, $\mathrm{Ca}$, and $\mathrm{Mg}$ in general, were likely contributing factors to the poor growth and presence of chlorosis in the leaves of these treatments.

Few studies with humates have focused on woody plant nutrition. Similar to the results of our study, Fardossi et al. (1990) found only a slight increase in petiole $\mathrm{K}, \mathrm{Ca}$, and $\mathrm{Fe}$ in potted 'Grüner Veltliner' vines growing in $\mathrm{P}$ deficient soils treated with manures. These workers also showed that although $\mathrm{Cu}$ and $\mathrm{Zn}$ uptake was enhanced, these elements appeared to remain in the roots. This phenomenon also may explain why high levels of granular GM in our study stimulated root formation, but failed to promote shoot growth, and led to leaf chlorosis. Our results nonetheless indicate that commercial humates may be used at moderate levels in conjunction with a complete fertilizer to stimulate growth of grapevines in coarsetextured soils.

\section{Literature Cited}

British Columbia Ministry of Agriculture, Fisheries, and Food. 1993. Production guide for commercial grape growers. Extension Systems Branch, Victoria, B.C., Canada.

Bryan, H.H. 1976. Response of tomatoes to seed and seedling applications of humates and alpha-keto acids. Proc. Fla. State Hort. Soc. 89:87-90.

Burdick, E.M. 1965. Commercial humates for agriculture and the fertilizer industry. Econ. Bot. 19(2):14-18.

Fardossi, A., J. Barna, E. Hepp, C. Mayer, and S. Wendelin. 1990. Einfluss von organischer Substanz auf die Nahrstoffaufnahme durch die Weinrebe im Gefassversuch. Mitt. Klosterneuburg 40:60-67.

Le Roux, E.G., M. Peisach, C.A. Pineda, and M.A.B. Pougnet. 1988. The toxic effect of aluminum in vines. J. Radioanal. Nuclear Chem., Articles 120:97-104.
Linderman, R.G. 1989. Organic amendments and soil-borne diseases. Can. J. Plant Pathol. 11:180183.

Neilsen, G.H., D.S. Stevenson, and A. Gehringer. 1987. The effect of NPK fertilization on element uptake, yield, and fruit composition of Foch grapes in British Columbia. Can. J. Plant Sci. 67:511-520.

Rauthan, B.S. and M. Schnitzer. 1981. Effects of a soil fulvic acid on the growth and nutrient content of cucumber (Cucumis sativus) plants. Plant \& Soil 63:491-495.

Schnitzer, M. and P.A. Poapst. 1967. Effects of a soil humic compound on root initiation. Nature (London) 213:598-599.

Senn, T.L. and A.R. Kingman. 1973. A review of humus and humic acids. South Carolina Agr. Expt. Sta. Res. Ser. 145:1-18.

Stevenson, D.S. 1975. Responses of 'Diamond' grapes to irrigation frequency with and without cover crop. HortScience 10:82-84.

Tan, K.H. and V. Nopamornbodi. 1979. Effect of different levels of humic acids on nutrient content and growth of corn (Zea mays L.). Plant \& Soil 51:283-287. 